\title{
Ocular Gnathostomiasis in Brazil: A Case Report
}

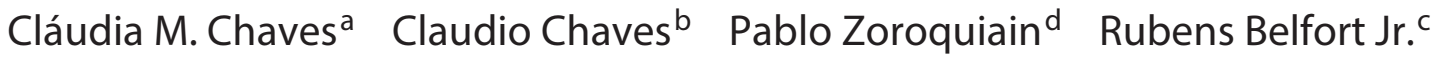 \\ Miguel N. Burnier Jr. ${ }^{d}$ \\ ${ }^{a}$ Ophthalmology Department, Nilton Lins University, and ${ }^{b}$ Clinical and Surgical Department, Amazonas Federal \\ University (UFAM), Manaus, and ' Ophthalmology Department, Medical School, São Paulo Federal University \\ (UNIFESP), São Paulo, Brazil; d Ocular Pathology Laboratory, McGill University Health Centre (MUHC), \\ Montreal, Que., Canada
}

\section{Key Words}

Ocular Gnathostoma · Helminths · Parasitosis

\begin{abstract}
Gnathostomiasis is a parasitic disease caused by nematode larvae ingestion of 15 known species of the genus Gnathostoma (one of the Gnathostomatidae family members). This parasite uses freshwater fish as a host and can infect - through the consumption of raw fish or their viscera - other animals such as dogs, cats, chickens, pigs, and humans. This parasitic disease, with humans acting as hosts, has been known since 1945 (India), and ocular complications have been known since 2004 (intravitreal; also described in India). Latin American countries, especially Mexico and Peru, have reported cases of the disease since 1970. The first dermatological case was reported in Brazil in 2009 (the individual had acquired the disease in Peru). This article describes the first reported ophthalmic case of the disease in Brazil and refers to a male patient, 30 years old, living in the municipality of Juruá, Amazonas State. The disease evolved within 30 days through a fistulized tumor in the inner corner of the lower eyelid. Following excision, the anatomical and histopathological examination revealed the presence of a different parasite species from other previously known genera.

(c) 2016 S. Karger AG, Basel
\end{abstract}

\section{Introduction}

Gnathostomiasis is a parasitic disease caused by infection with larvae of nematodes of the genus Gnathosto$m a$, superfamily Thelazioidea. The intermediate hosts are small crustaceans, amphibians, fish and birds [1]. There are records of this infection in humans in the Far East (India: 1945, China: 1949), Thailand and countries in the Americas (e.g. Mexico and Peru) where the habit of eating raw or undercooked meat has been increasing [2-5]. The larvae are released in the intestine and then migrate through the body but are unable to complete their normal life cycle in humans. The most common symptom is the presence of painful and pruritic migratory subcutaneous edema. Gnathostoma larvae can cause skin disease or spread to other organs and systems such as the eyes, lungs and central nervous system. Eosinophilic meningitis and ocular larva migrans may occur with devastating results including paralysis, subarachnoid hemorrhage, and permanent visual loss. There is no commercially available serological diagnostic test. Surgical removal is both diagnostic and curative [1-7].

\section{KARGER}

E-Mail karger@karger.com www.karger.com/oop
(C) 2016 S. Karger AG, Basel

2296-4681/16/0023-0194\$39.50/0
Cláudia M. Chaves

Rua Rio Javari, 445 ap 801

Manaus, AM 69053-110 (Brazil)

claudiamachaves@gmail.com 


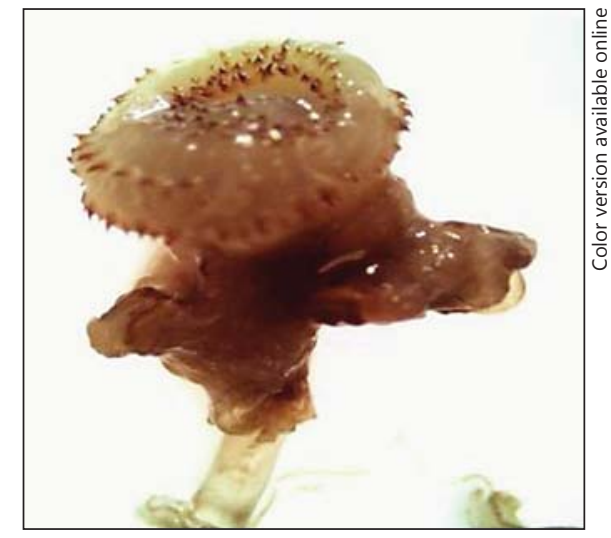

Fig. 1. Parasitic scolex with concentric rings and hook-like denticles. No suction elements are observed.

\section{Case Report}

A male patient, 30 years old, residing in the Fortes das Graças community, municipality of Juruá, Amazonas State, Brazil, where he had lived since birth presented to the city of Manaus hospital. In this community, eating habits consist mainly of fish caught in local rivers.

The patient had a fistulized tumor in the inner corner of the lower eyelid of his left eye, containing a living being similar to myiasis with an evolution of approximately 1 month. The patient also complained of gastric symptoms, such as heartburn and nausea. Excision and a histopathological study (fig. 1) were performed and revealed a nematode parasite of the Gnathostoma genus without, however, the species being identified.

\section{Discussion}

Gnathostoma infections result from ingestion of raw or undercooked meat infected with nematode larvae, such as fish, chicken, etc. [1-9]. To date, 15 species of nematode parasites [10] are known. However, only the G. spinigerum, G. hispidum, G. doloresi, G. nipponicum and G. binucleatum species are the those found most frequently. Our histopathological study finding was not conclusive in identifying any of the currently known species.

The life cycle of the evolution of Gnathostoma shows some flexibility [11] - it requires two intermediate hosts and one definite host. There are also transport hosts.

Humans are regarded as accidental hosts and carry third-stage larvae; on rare occasions, immature adult forms [11] have been recorded.

Numerous species of freshwater fish act as secondary hosts where those early larvae develop into mature thirdstage larvae. Parasites reach maturity between 3 and 12 months after ingestion inside the host's stomach or esophagus.

The larvae migrate through the gastric or esophageal wall to the liver and subsequently to the subcutaneous tissue and/or other organs [11].

The diagnosis of Gnathostoma sp. infection is made by clinical evaluation, epidemiological history and histological findings of dense eosinophilic infiltrate, or by identification of the adult worm.

In our case, the diagnosis was made by histopathological examination, which identified nematode parasites of the Gnathostoma genus.

Humans are not suitable hosts for the parasite, ingestion of infected fish causes migration of the infective form from the stomach via the intestines to dermal, subcutaneous tissue, often associated with localized pain, pruritus and erythema. Ocular involvement may occur years after the initial infection. Therapeutic success depends on early and complete surgical removal, which could be lifesaving since no antiparasitic drugs are available to treat the ocular involvement [12].

Parasitic diseases of human and animal populations are common in low-resource countries. Epidemiological investigations are not available from places where the disease is endemic. Literature on the research-to-policy process from low- and middle-income countries is scarce. Policy makers have a variable understanding of the economic analysis and burden of the disease measures [13].

The case presented in this article is caused by an unknown Gnathostoma species and raises the hypothesis that the disease may become an emerging infection in Brazil, notably in areas where local populations have a habit of eating raw or undercooked fish. Furthermore, the increasing consumption of raw fish in Japanese restaurants across the country is worthy of note.

\section{Statement of Ethics}

All procedures followed were in accordance with the ethical standards and with the Helsinki Declaration of 1975, as revised in 2008.

\section{Disclosure Statement}

The authors certify that they have no affiliations with or involvement in any organization or entity with any financial interest (such as honoraria; educational grants; participation in speakers' bureaus; membership, employment, consultancies, stock ownership, or other equity interest; and expert testimony or patent-licensing arrangements) or nonfinancial interest (such as personal or professional relationships, affiliations, knowledge or beliefs) in the subject matter or materials discussed in this paper. 


\section{References}

1 Goldman L, Schafer AI: Goldman Cecil Medicine, ed 24. Philadelphia, Saunders Elsevier, 2014.

2 Dani CMC, Mota KF, Sanchotene PV, et al: Gnatostomíase no Brasil - relato de caso. An Bras Dermatol 2009;84:400-404.

3 de Górgolas Hernández-Mora M, Fernández Guerrero ML: Gnathostomiasis: an increasing disease among travelers (in Spanish). Med Clin (Barc) 2005;125:190-192.

4 Moore DA, McCroddan J, Dekumyoy P, Chiodini PL: Gnathostomiasis: an emerging imported disease. Emerg Infect Dis 2003;9: 647-650.

5 Del Giudice P, Dellamonica P, Durant J, Rahelinrina V, Grobusch MP, Janitschke K, et al: A case of gnathostomiasis in a European traveller returning from Mexico. Br J Dermatol 2001;145:487-489.
6 Diaz Camacho SP, Zazueta Ramos M, Ponce Torrecillas E, Osuna Ramirez I, Castro Velazquez R, Flores Gaxiola A, et al: Clinical manifestations and immunodiagnosis of gnathostomiasis in Culiacan, México. Am J Trop Med Hyg 1998;59:908-915.

7 Akahane H, Shibue K, Shimizu A, Toshitani S: Human gnathostomiasis caused by Gnathostoma doloresi, with particular reference to the parasitological investigation of the causative agent. Ann Trop Med Parasitol 1998;92: 721-726.

8 Hennies F, Jappe U, Kapaun A, Enk A: Gnathostomiasis: import from Laos. J Dtsch Dermatol Ges 2006; 4:414-416.
9 Baquera-Heredia J, Cruz-Reyes A, FloresGaxiola A, López-Pulido G, Díaz- Simental E, Valderrama-Valenzuela L: Case report: ocular gnathostomiasis in northwestern Mexico. Am J Trop Med Hyg 2002;66:572-574.

10 Hale DC, Blumberg L, Frean J: Case report: gnathostomiases in two travelers to Zambia. Am J Trop Med Hyg 2003;68:707-709.

11 Berrueta TU: Gnasthostomosis o Gnathostomiasis (September 28, 2015). http://www. facmed.unam.mx/deptos/microbiologia/ parasitologia/gnathosmosis.html (retrieved February 1, 2016).

12 Shreekant T, Nirupama C, Bibhudutta R: Intraocular Gnathostoma spinigerum: a case report. Cases J 2009;2:9370.

13 Rathinam SR, Annamalai R, Biswas J: Intraocular parasitic infections. Ocul Immunol Inflamm 2011;19:327-336. 